DOI https://doi.org/10.36059/978-966-397-111-7/26-45

\title{
THE HISTORICAL FACT IN THE CONTEXT OF POST-NON-CLASSICAL SCIENCE
}

Kosmyna V. G.

\section{INTRODUCTION}

Studying the methodology of civilization analysis of the historical process foresees understanding the range of categories of historical science in a certain perspective aiming at establishment of a sociocultural component there. It is directly related to the fundamental category of historiography, namely, a historical fact. In addition, modern post-non-classical science requires such rethinking not only in relation to the "object" of historical studies, but also their "subject", that is, historical science, which is an indisputable historical fact itself in the life of civilizations, at least during the last one and a half or two centuries. In this sense, "a historical fact" is both a category of cognition and a category of self-knowledge for historical science, which undoubtedly affects its status and meaning. Its problematic nature should be analyzed on the general background of the entire science evolution as a separate area of social activity.

The fact has been and remained the basic component in any field of scientific knowledge. However, its interpretation in different periods of the history of science was different. In classical science (in the $17^{\text {th }}-19$ th century), it was considered to be the ascending repetitive unit ("an atom") of scientific research, which objectively reflects reality, if it can be proved by the experiment. Non-classical science (the 20th century) states the dependence of its values in complex and "non-obvious" systems (for example, in quantum mechanics) under the conditions, means and theoretical substantiation of the experiments themselves, and therefore, it requires additional recognition by the relevant scientific community for the confirmation of its scientific status. Post-non-classical science, having formed in the last three decades, considers a fact as an element of a complex system of interconnections, capable of self-organization, which includes a person, and therefore, in the assessment of the fact the 
purposeful features of the subject are added to the previous characteristics, as well as conditionality and limitedness of the latter by the state of the intellectual sphere itself (noosphere) and the cultural meaning of the age ${ }^{1}$.

All these changes in the interpretation of the fact occurred mainly in the field of natural sciences. However, in the social and humanitarian sciences, especially in history, it was more difficult to resolve the issue of the fact. The point is not only that the deeper the history was, the less preserved the sources were, or that it was impossible to carry out direct experiments to verify one or other empirical data. First of all, instead of the unequivocal scheme of establishing the fact along the line: the subject - the object, which was usual for natural science, historical science, usually, had to deal with a fundamentally different scheme: the subject (historian) - the subject/the object (author of the source/source) the subject/the object (human consciousness/human action in history). And that fact still caused ambiguity in determining the very object of the study: what (event) or who (the person) should be studied at first? This problem of the subjective-objective dichotomy of the historical fact resulted in the main difficulty in its study, and hence, in the scientific study of the history itself.

So, in the article we will try to outline the content of the historical fact issue at the early stages of scientific development and possibilities of its solution within the framework of post-non-classical science, namely, in N. Luhmann's theory, as well as to determine parameters for the implementation of new interpretation of the fact in civilization studies.

\section{Immanent Difficulties in the Analysis of the Historical Fact}

In the age of classical science as well as non-classical one with some remarks, the fact, following the pattern of natural sciences, was considered as objective reality, as "a thing". . Only different strategies for its study were proposed: through a scientific analysis of historical sources as direct evidence of it (positivism); or through hermeneutical "understanding" of subjective actions of historical characters (Neo-Kantianism). Non-classical

\footnotetext{
${ }^{1}$ Див.: Мелков Ю.А. Факт в постнеклассической науке. К.: Издатель ПАРАПАН, 2004.

2 Див.: Дюркгейм Э. Метод социологии // Дюркгейм Э. Социология. Ее предмет, метод, предназначение / Пер. с фр. М.: Канон, 1995. С. 18-40.
} 
science focused on the problem of the fact-source, having discovered, according to the pattern of quantum physics, the methodology of indirect study of sources, their "interviewing" not so much about events but about language, culture, mentality, psychology of people of historical time. This initiative of the French School of "Annales" (M. Bloch, L. Febvre), combining positivism and Neo-Kantianism, resulted in the attempts to reconstruct the stable social and mental structures in history and contributed to the emergence of powerful streams of structuralism and different versions of "new scientific history" associated with it in one way or another in the second half of the 20th century. However, the issue about the theoretical "load" of the historical fact has already arisen here, as well as its inevitable subjectivity and distortion by the historians themselves, relying on their discovery and analysis of a particular logically derived theory. In the USSR, by the way, in the 1980s the historians also began to recognize the historical fact as "double subjectivized" - by the author of the source and the historian ${ }^{3},-$ but they demonstrated confidence that relying on Marxism as "a single true scientific theory" provided necessary objectivity in the studying of facts.

Significant difficulties in the operation of "a historical fact" as something certain in many respects are due to the internal logical contradictions of this category. After all, the term "historical" refers to the variability, fluctuation, whereas the concept of "fact" (Latin factum made) points to another thing, namely, the completeness of something, the ending, the result. By the concept of a "fact" we, in fact, "stop" the fluctuation (procedurality) of the "historical", we take out one or another line (event, phenomenon, process) and begin to analyze it then as something separate, constant, self-sufficient, appealing both in its interpretation and in conjunction with other "facts" to a logical, sufficiently rational scheme for us. Then not the events and sources themselves, but the logical scheme in the form of theories or metaphors like "mechanism" or "organism" dictates the vision of the historical process. So, "as soon as it comes to the long evolutionary processes in time, consisting of a set of events, then quite obvious gnoseological

\footnotetext{
${ }^{3}$ Ковальченко И.Д. Методы исторического исследования. 2-е изд., доп. М.: Наука, 2003 [1987]. С. 143.
} 
barriers between "following the sources", "studying the source", "studying the historical process" appeared ${ }^{4}$.

The problem of substituting immanent procedurality of events logical and inevitably artificial - correlates with one more problem of historical facts - their perceptions as heterogeneous, "multi-ordinal". History which was the only science about the past long ago ("science of memory" in the concept of F. Becon) - in the 19th-20th century was in considerable methodological dependence on other sciences - sociology, economics, political science, cultural science, etc., which developed theories and methodical tools for studying "their" subsystems yet clearly distinguished in the structure of the Western society of that time. As a result, in historiography, especially in generalizing works, the "classification" - the consideration of the past as actually different histories - political, economic, social, and "cultural" became common. This made the resolution of the ancient problem of integral and systematic study of the world history extremely complicated: both in the paradigm of a one-line world-historical process and in the paradigm of the history of local civilizations.

The obviousness of the specificity of cultures themselves and the development of various cultural and historical regions required the search for manifestations of this specificity in elementary historical facts further. However, there were no methods of such search in the means of historical science, and it forced the researchers of civilizations to turn to the philosophy of history, or even metaphysics. M. Y. Danilevsky, O. Spengler, and to a certain extent A. Toynbee, in explaining the spatialtemporal connections between the facts and the significant differences between civilizations, relied on the analogy between civilizations and organisms, not deduced from particular facts, and imposed on them from the outside - from the theory. At the same time, the authors mentioned, in fact, openly declared the position of the external observer, from which they examined the world history and which is latently present in any study of history. There it was the position of the Absolute Observer over the entire human world - God, Divine Providence.

\footnotetext{
${ }^{4}$ Ионов И.Н. Логические модели и источниковое знание: проблемы соотношения // История и синергетика: Методология исследования. М.: КомКнига, 2005. С. 45.
} 
Therefore, in the traditional interpretation of the historical fact for the 19th-20th century a number of strong methodological contradictions, with the most significant of which being its subjective-objective dichotomy, have appeared. The issue of the historical fact turned, according to the famous historian A. Y. Gurevich, into the "cursed" problem of historical knowledge, "unsolved for generations of historians". All its depth was demonstrated by postmodernism ruled in culture in 1970-1980s, having obtained a significant philosophical justification in post-structuralism (J.-F. Lyotard, G. Deleuze, M. Foucault, etc.) and deconstructivism (J. Derrida, D. La Carpe, etc.). Structuralist's constructs in social sciences were dissipated as incompatible with the actual procedurality of history (event, case, freedom), and "meta-narratives" - the great theories of modernity (of modern times) of philosophical, historical, sociological, political science - as a reflection of only literary practices and structures of thinking of a certain cultural age. And in the historiography, H. Wyatt, R. Bart, F. Ankersmit showed the direct influence of speech structures on the designing of scientific and historical facts by scientists, the connections between them and the entire presentation of historical material in general. So, if classical science problematized the object of study, namely the historical fact of reality, then non-classical science focused on a historical source, but now the subject of science itself, namely, the historians have become problematized. Their "objectivity" was established as the precondition of their aspirations, reason, style of thinking, etc., by objective language practices of a certain age, that is, by culture and society.

The formation of a new paradigm in science - post-non-classical was the response to this postmodern challenge, which noticeably touched the natural sciences. Its general methodological basis was formed by synergetics (I. Prygozhin, H. Haken, E. Jantsch, etc.), studying nonlinear high-complex systems characterized by self-development, selforganization, synchronicity and irreversibility of changes, etc. These comprehensive systems (especially biosphere, noosphere, meta galaxy, civilization) include a person as well and, therefore, do not allow the position of an "outside observer" for science and a scientist as it was in

5 Гуревич А.Я. Что такое исторический факт? // Источниковедение. Теоретические и методологические проблемы. М.: Наука, 1969. С. 88. 
classical and non-classical science, leaving them only a place for "intrasystem dialogue" with the phenomena studied. However, attempts to apply the synergetic paradigm directly in historical science have not changed its conditions a lot, since they leave the "tangle" of accumulated problems with the historical fact aside.

In this perspective, the pioneering sociological systems theory of German sociologist, Niklas Luhmann (1927-1998), which if not able to remove completely, but can minimize the severity of these problems and is of great interest in the methodology of history. The scientist set forth the theory in a generalized form in the book "Society of the Society", five chapters of which were published as independent volumes and in Russian language ${ }^{7}$. In scientific literature the issue of implementation of the theory mentioned to the analysis of the historical fact has not been considered yet.

It should be noted immediately that the theory of $\mathrm{N}$. Luhmann is presented in an unusual way for humanitarians both in the sense of the arguments presented in it and in the terminology. As in post-non-classical theory, it has an interdisciplinary nature, organically combines elements of the theories of social-humanitarian and natural science (from the field of sociology, philosophy, cybernetics, cognitive sciences, theory of communication, theory of evolution, theory of consciousness), it is based on their conceptual apparatus, and, moreover, claims to be universal and it is quite formalized. Its various aspects reflect and at the same time modify the achievements of systemic sociological theories of T. Parsons (the theory of social action) and J. Harbermas (the theory of communicative action) and directly overlap with the synergetic theories of I. Prygozhin and H. Haken, the theory of autopoiesis (self-creation) systems of Chilean neurophysiologists U. Maturuna and F.Vareli, the theory of second-order cybernetics of the Austrian-American physicist H. von Foerster. Comprehensive substantiated concepts of the communicative system of society, systems evolution of society and systems differentiation of society are its integral parts.

\footnotetext{
${ }_{7}^{6}$ Luhman N. Die Gesellschaft der Gesellschaft. Frankfurt am Main: Suhrkamp Verlag, 1977. $1150 \mathrm{s.}$

7 Луман Н. Общество как социальная система. Пер с нем. М.: Изд-во «Логос», 2004; Его же. Медиа коммуникации. Пер с нем. М.: Изд-во «Логос», 2005; Его же. Эволюция. Пер с нем. М.: Изд-во «Логос», 2005; Его же. Дифференциация. Пер с нем. М.: Изд-во «Логос», 2006; Его же. Самоописания. Пер с нем. М.: Изд-во «Логос», 2009.
} 
According to the theory, society consists of communications between people exclusively. Each communication as an individual operation of the communicative system includes three elements: the addresser's message the information contained in the message - understanding the message (the extraction of personal information) by the addressee. It is also an operation of observation of the system. Observing the reference of messages to previous and subsequent operations of the system (selfreference of communications), the system refers to an internal, consistent meaningful relation of its operations. Observing the reference of information to the relevant events in the environment (hetero-reference of communications), the system refers to the external, reactive meaningful relation of its operations with processes in the outside world. By differentiating between itself and the environment, the system constructs itself (in relation to the world). Differences come to the place of traditional scientific "objects" with their inevitable subjective-objective dichotomy. In communication the objective and the subjective are mutually annihilated.

In Luhmann's theory, the mechanism of the society evolution as a communicative system is revealed. It includes variations in communications, the selection of some of them by the dominant structure of meaningful expectations and re-stabilization of society under the new conditions. Separately, N. Luhmann analyzes four forms of systemic differentiation of society: segmental form is based on verbal communication, centered-peripheral and stratification forms are based on written language, and functional form is based on a book-printing.

\section{Historical Fact in the Science of Post-Non-Classical Age}

We can evaluate the prospects of the methodological application of the Luhmann's theory in historical science, especially in the systemcivilization analysis of the historical process. It should be noticed immediately, that these prospects in no way foresee the refusal of the history from "classical" trends of its knowledge, namely, direct empirical studies, the discovery of unknown facts of the past, or the same thing the "covering of the white spots" of history. It is about the other field of studying - historical generalization, system analysis, where as experience of the 19th-20th century shows, historical thought never created the 
methods of society integral description based on the facts that it had discovered. The post-non-classical theory of N. Luhmann, corresponding with synergetic, autopoietic and other modern theories, makes such a holistic description possible, but at the same time it allows overcoming other traditional difficulties with the historical fact. However, it requires a completely different view of the fact itself. If in society there is nothing but communications, then one should use the same perspective to look at historical facts. The sociologist himself points out that "under the communication (as, in a narrower sense, and under the operation) a certain event taking place in a certain historical way, and therefore depending on the context is understood"8. Still one can make at least three conclusions from this definition: 1) each specific historical event (historical fact) is a communication, and each communication is a fact; 2) since the effectiveness of communication depends on its understanding by the recipient, then any conversation, act, action, work of art, text (scientific, religious, artistic), demonstration of experience (values, love) and other manifestations of human activity, that is, any fact of reality is communication, if it becomes a message to other people deliberately or unknowingly, if it is understandable to any degree; 3) the meaning of certain communication (a fact) entirely depends on the context, formed at the intersection of the meaningful lines of various social processes and phenomena that are happening now at this place.

Thus, the old interpretation of the historical (social) fact as a real object, a thing, a certain entity that is subject to cognition is rejected decisively. According to O. Antonovsky, in N. Luhmann's theory, people, consciousness, organisms, artifacts "lose their significance as the social fact in his Durkheim's sense", to that end, they can not directly "join" in communications: "Not an object, but its description, its representation in the form of a theme, or more precisely, its thematizing communication becomes the main and only social fact from now on. All subjects of communication (its external worlds: people, consciousness, objects) can be represented only communicatively, that is, within the society, which thus becomes a closed sequence of operations that relate only to one

\footnotetext{
${ }^{8}$ Луман Н. Общество как социальная система. С. 72-73.
} 
another"9 . However, it changes the methodological approach to the facts. Luhmann emphasizes specially that "the most radical restructuring ... consists in moving from thinking about objects to considerations on differentiation" $"$. The perspective logic is the following here. If there is no traditional object, then there is no traditional subject, that is, the issue of subjective-objective dichotomy is removed from the agenda. Everything in society is its internal communications. In the context of the issue studied, the fact of reality is communication, and the fact-source is communication, and the scientific study of them (the so-called scientifichistorical fact) is also a communication that the historian introduces in the subsystem of science and into society as a scientific publication.

So, how can communication "study" communication? Here, the meaning of the "differentiation", emphasized by N. Luhmann, appears. It is the meaning of observation inherent in almost every communication, and it leads to differentiation of self-reference (messages) and heteroreference (information about the outside world) in it. The problem, however, is that this observation can focus either on one side of the form of communication (why is it reported here?) or on the other (what is new they are talking about here?), but it can not be both at the same time here and there, and even more it can not establish exactly their differentiation. That is, the very meaning of communication, its belonging to one or another meaningful code is not discussed in communication, it does not demonstrate it. However, it can be detected and described by way of observation on observation that is carried out purposefully by historical science, or observation of the second order (this notion is introduced by N. Luhmann from cybernetics). Scientific communication can simultaneously observe both self-reference and hetero-reference of communication-fact, to differentiate them, to establish their interdependence, to compare them with previous communications of the same meaningful orientation, with information about the whole external world of this communication, and eventually to establish and describe the certain historical significance of this historical fact.

\footnotetext{
${ }^{9}$ Антоновский А. Никлас Луман: эпистемологические основания и источники социологического конструктивизма // Луман Н. Общество как социальная система. С. 208-209.

10 Луман Н. Общество как социальная система. С. 63.
} 
Such analysis is often carried out on the basis of the study of written communications-sources, which either directly represent the communication-fact and contain it, or describe it from the outside, in its hetero-reference. In the second case, the source, depending on its content, may be the observation of the second order in relation to the primary communication-fact. However, the science, which is its observation, should also analyze and evaluate through the differentiation of its own self-reference and hetero-reference, that is, to reveal its own meaning. In general, every source is the same communication-fact of the historical evolution of the society system, as well as others, and it should be taken into account as part of the whole historical process.

In the same way, the works of historians (as well as scientists from other fields of science) are communications-facts in the system of society and can be evaluated on the basis of differentiating them from self- or hetero-reference. Essentially, the scientist themselves as a system of consciousness, which, according to N. Luhmann, belongs not to a society, but to the outside world, can perceive the fact of the past well, and society itself as an external object ${ }^{11}$, but their scientific message (essay) is a communication - an integral component of a social communication system. The historical science can not consider society and its history from outside. Being one of communicative subsystem of a modern society, it depends on general social "context", and it performs the function of its self-description in the society in historical retrospective.

From stating communicative operations as elementary historical facts - because there is no other factuality in society, and each communication is actually "a fact", that is done, completed - a significant logical consequence arises: the system of society at each given moment is a sequence of historical facts of one or another level of universality, speaking this way "it is weaved of facts". From stating the same historical facts as communications - and all communications are micro-processes that continually change one another and turn into the comprehensive social macro-process - not less important conclusion follows about the total procedural functioning of the social system and all its facts, about procedurality, which, however, is not spontaneous and

\footnotetext{
11 Луман Н. Общество как социальная система. С. 92.
} 
chaotic, but subordinated to certain meaningful lines of communication and their intersecting. Factuality and procedurality of the communication system mean that every fact brings irreversible changes to the system, but at the same time it is itself a product of a constantly changing system of meanings, it can only be recognized by belonging to this system, and thus, be considered and changed. Therefore, it is unique in terms of meaningful content and is generated by a specific configuration of meaningful structures in social and mental systems at a certain point in time. Since the repetition of such configurations is impossible, because the fact itself changes it, the assumption about the repetitiveness of the facts is groundless, and therefore - about domination of some rational laws in the history.

According to the Luhmann's evolution theory, various factscommunications can have a different effect on the historical process: some of them make changes to the system on a purely local level, while others are on a system-wide basis. Each fact-message, able of making visible changes in the life of society, must be in the circle of already known meanings (to be clear) and at the same time to be a deviation from the established norm of any of them, which is possible due to yes-nocoding of language and meanings. The degree and direction of deviation (variation) are not programmed and can be considered random. After all, many different offers can be made in the communication. The selection of one of them by the structure of meaningful expectations in a society also depends on the temporal state of this structure and does not necessarily turn out to be optimal (here we have contingency of choice). Restabilization of the system after the structural changes made, may either improve its state, or worsen, or even ruin it over time (contingency of restabilization way). Does this mean that there is a total contingency in society? - Definitely not. Necessity exists at the level of evolutionary functions itself. Thus, the necessary, that is, naturally determined, is the following: for communications - the variation of information, for meaningful structures - selection of the most suitable variations and rejection of the rest, for the system - achievement of stability, to which it always aspires.

Such a contradictory combination of necessity and contingency in the history characterizes all its dynamics. The assessment of the historical 
process from the view of rationally constructed and logically consistent theories is of little help in its understanding, except for the discovery of one or other "irrational" plots in it. Therefore, the disclosure of the communicative meanings of historical facts and their "survival" on the complex path of variation-selection-re-stabilization is much more productive in historical analysis. After all, some events, some ideas and undertakings, having passed through this "sieve" of historical practice, eventually radically changed the state of society and acquired the significance of "outstanding facts", and their initiators gained the status of "great personalities", while the authors having much more useful ideas sometimes did not even find an understanding in society.

Luhmann's methodology does not reject the accumulated experience of establishing empirical facts of history by historiography, the fact that some event took place. However, this methodology allows us to go further - to the systematic analysis of a particular event, and through it the entire historical process, based on the statement that "events create structures, and structures direct events" $"$. For meaningful analysis of the fact it is necessary to clarify the following: a) what was the variation of the new communication; b) what meaningful structures delegated it; c) what new meaningful structures it created; d) how it changed the system of meanings in its re-stabilized state, or may be it, on the contrary, misbalanced it? "Thus, - the sociologist writes, - "the evolution theory gives rise to a practically infinite program of historical research"13. It is possible to reveal the same historical meaning ("historical significance) of a certain fact only within the limits of the dynamic system of society, identifying the dominant structure of meaningful expectations in it, which ensured the selection of the fact and its "continuation" in new communications.

And, perhaps, the most important achievement of the Luhmann's methodology is precisely that it allows studying the entire system of society in its dynamics and civilization meaningful specifics by historical and scientific methods that require deliberately moving from sources to scientific historical knowledge. If the traditional methodology of history had no tools at all for a holistic civilization analysis of society and had to

\footnotetext{
12 Луман Н. Медиа коммуникации. С. 19.

13 Луман Н. Эволюция. С. 106.
} 
consider separately its political, economic, societal, cultural subsystems, relying on the methods of the corresponding sciences and hoping in vain for their uncontroversial connection, then such toolkit has appeared now. The basic unit (a kind of common denominator) in the study of all fields of social life is meaningful communication, always having the same, three-component structure. Differences can relate to their own communication meaningful lines (self-references), but they do not isolate the subsystems of society from each other, since in their other heteroreferences of communication, they always observe processes in other subsystems and accordingly "correct" their own meanings. This is how the main methodological setting of post-non-classical science: "unity in diversity" is implemented.

\section{The Historical Fact in Civilization Studies}

Therefore, N. Luhmann's systems and communications theory discovers the prospect for a systematic study of the history of civilizations no longer within the philosophy of history, as it has been before, but directly within the framework of historical science - on the basis of the establishment of meaningful relations of facts-communications. At the same time, his theory of systems differentiation determines the ontological and epistemological parameters of civilization analysis: 1) Civilization has not yet included unwritten archaic, segmental societies. 2) Modern Western society can no longer be studied as a classic civilization, in which, based on its own media-codes, functional systems of politics, law, economy, science, art, intimate relationships, religion, morality have separated, and, to the extent in which these systems have spread in the world - as well as the relevant public sectors in other regions. 3) Social differentiation in societies of "high cultures", as $\mathrm{N}$. Luhmann named civilizations, includes the division into a center and periphery and/or strata as partial social systems. 4) The main integrating mediums in civilizations are written language, power, religion, and morality. 5) There were from 20 to 30 such civilizations in the history of mankind (obviously, N. Luhmann relies on the classification of A. Toynbee and his followers here).

Such theory of differentiation was developed by other sociologists (T. Parsons, S. Eisenstadt). However, N. Luhmann radically changes its 
meaning, combining it with the communications theory. Now civilization is not an abstract structural model, but a "living tissue" of facts. Moreover, these facts are not scattered chaotically in space and time, they are not collected artificially in conglomerates for the convenience of the analysis of "structures", but occupy a natural place in the system of society at each period of time, uniting on the ground of belonging to certain or other meaningful lines and their intersections. Tracking these lines, revealing selfreference and hetero-reference in the meaningful systems of facts enables a "comprehensive" description of the civilization functioning.

The most important thing is the ability to make such description by written sources, which often serve as important system-forming elements (communications) in civilization themselves, such as sacred texts that are comprehensive self-descriptions of not only religions but also societies for which they are decisive. In addition to sacred texts, which are unchanged, although in the course of time they can be "read" with new emotional shades, as well as supplemented by relevant comments, the texts (documents) of the power are of general public nature, which, of course, are agreed with sacred texts, but peculiar self-description of power and public relations around the power. Less comprehensive for civilization are self-descriptions of partial social systems - aristocracy (dividing into a center and periphery) or individual strata, and within them - social organizations (shops, guilds, etc.) or territorial social units. Even specific situations, events may have their own descriptions and self-descriptions. Thus, the social hierarchy is reflected in the text hierarchy and the corresponding hierarchy of meanings, which is subject to analysis in the corresponding scientific observations. These meanings may vary, but mainly at the low level of social communications and within the limits allowed by the dominant meaningful structures. After all, a significant variation of meanings at the upper levels (power, and especially religion) is risky for society and threatens it with a split, or even a collapse, that is why the system usually strives to prevent it.

Despite the presence of various civilization meaningful lines in communications (economy, trade, law, power, marital relations, etc.) and the inevitable and necessary variation of meanings, civilization has demonstrated an amazing integrity, orderliness and preserved its own identity for centuries and millennia. It depends on the fact that, it has a 
universal medium, in addition to religion and authority, in which everyday communications are monitored and controlled. It is a morality that clearly separates all actions in different fields into good and bad, approving the first and denying the latter. It has its own code - respect/disrespect, which suppresses the self-reflection of potential functional media codes. The morality, which in various strata connected with ethics, and may have its own shades, is usually based on the past, on the "wills of the ancestors", but gains its highest meanings in religion (although historically it may be vice versa - religion, first declaring ethical norms, agrees them with the existing morality). Civilizations, therefore, have a traditionalist nature (including the pre-modern Western Europe), which in all the troubles of changes, hold the past from old centuries as a reference point. As a result, it is the religion based on the morality of everyday life that appears the very meaningful structure, performing the selection of meaningful variations, and thus retains the traditional lines of meaningful communications.

In the "laces" of more or less movable meanings a "face" of society being its culture is revealed. N. Luhmann is skeptical about the possibility of creating some general theory of culture, because culture does not create meanings, but is created by meanings; therefore, it always has a very specific, changing form and content in time. The sociologist writes: "In the interaction of all media communications - languages, media distribution and symbolically generalized media - there is a condensation of what can be called by one common notion of culture. Condensation should mean that the meaning used every time, on the one hand, remains the same for repeated use in different situations (since otherwise there would be no reuse), but on the other hand, it is confirmed and enriched by the meanings, which can no longer be reduced to one form"14.

Approaching to the culture as a system of condensed meanings, although dynamic, to a certain extent, it is possible to objectively carry out a general comparative analysis of different cultures and civilizations. It becomes possible by comparison that the common meanings of life in people of different civilizations are the same and predetermined by human nature itself. The science recognized the effect of biological instincts of people behind the emergence and functioning of such communicative

\footnotetext{
14 Луман Н. Медиа коммуникации. С. 259-260.
} 
media as power, property, intimate relationships long ago. Austrian ethologist, Nobel laureate K. Lorenz, always stated that social behavior "contains an instinctive meaning that is not subject to change under cultural influences" $"$. Differences between civilizations are revealed mainly in a different hierarchy of meanings, their different structural cohesion and combination, which is already due to features of the geographical environment, historical experience, psychology of ethnos, etc. Comparative-historical analysis of civilizations can be carried out by comparing forms of structuring the meanings in the communicative systems of the respective societies. It will allow us to reveal the specifics of each civilization and understand the unique content of life and development of each of them better.

It goes without saying that a direct comparison of certain factscommunications on the history of various civilizations (even facts of the "same type", that is, belonging to the equivalent subsystems of society) will not be cognitively productive if it is carried out beyond their internal civilization and, moreover, the peculiar historical context of the meaningful context. On the other hand, there is no sense in attempts to compare civilizations in their general meaning, since it is impossible to "derive the formula" of some "average" meaning of communication: the meanings are always certain. At the same time, one can speak about a certain style of communications inherent in every civilization. It concerns not the internal meaning, but the external form of social communications. Style is a kind of deviation, the direction of expression of action or events. In the structure of communication, it belongs not to information, but to the message, and serves its recognition and accelerates understanding. It can be regarded as a means of communication itself.

On the ashes of traditional civilizations with specific universal communications styles, the Western modern society is notable as well as world-wide communications spreading by it around the world. In civilization studies of the 19th-20th century - from M. Y. Danilevsky to S. Huntington - it was studied by using the same methods and techniques as for the rest civilizations of the past. However, the use of a single "arsheen" in their comparison only distorted the real picture of history and

\footnotetext{
15 Лоренц К. Обратная сторона зеркала. М.: Республика, 1998. С. 457.
} 
modernity - not to mention some predictions of the inevitable "decline of the West". The application of the Luhmann's sociological theory allows us to see the fundamental difference between the state of the modern West and other civilizations. As an ordinary civilization with a universal style and a universal media of communications, it has not existed for a long time. In 15th-16th century already in the Western society, the separation and self-constitution of functional communication systems as an individual systems of politics, economy, law, science, art, religion, morals, production, education, medicine, began and accelerated continuously. There is no single, universal media that would regulate all communications. Morality and religion have become as isolated systems as the rest. And these other systems, centering communications around their own codes, function independently, without any moral and religious coloring, and therefore easily spread outside the West itself, freely joined by new communications in the rest of regions. Their immanently "immoral" status allows them to easily establish themselves on the "canonical" grounds of traditional civilizations. Local moral and religious communication systems can not directly oppose them, because they do not distinguish the direct, which is, the moral-religious, "enemy" in them, which, for centuries, was Christianity (Catholicism), accompanied the colonization and strived to replace the local cults. Traditional religions can strongly (in the form of fundamentalism) react to innovations only when they can identify signs of "immorality" in the way of life, approved by functioning systems.

Individual functional communication systems of a global nature do not have a certain civilization meaning and can be identified as phenomena of a super-civilization or post-civilization. In the West, the systems of morality and religion criticized them, but no longer controlled. This new look of the Western civilization began to shape in the turn of the 17th-19th century, when adherence to the tradition lost the importance as the most essential value and civilization reference point for the society. Therefore, in the civilization analysis of the Western society of the 19th-20th century it should be borne in mind that in this period the facts-communications in various subsystems of society usually do not contain the traditional moral and religious component, and they are "grouped" mainly around their own meaningful codes, which should now be the reference points for historians 
when distinguishing self-reference and hetero-reference in the communications. It should be taken into account that all functional systems are structurally interconnected, and each noticeable fact (variation) in one system "echoes" (causing irritation) in others.

The texts created in the functional systems themselves and related fields of scientific knowledge are getting the main sources-communications for a general civilization analysis instead of sacred texts. They, and to more extent, generalized historical, sociological, and philosophical works are exactly the new self-descriptions of society, subject to observation of the second order and, thus makes civilization description possible. As for the description of non-Western societies, here it is necessary to distinguish between facts-communications of a traditional nature, the facts of the common functional systems here and the facts of conflict communications associated with the "collision of civilizations".

\section{CONCLUSIONS}

Making conclusions from the study conducted, it should be noted that there has been a range of difficult methodological issues in historical science that accumulated during the whole period of its developmental. The most notable of them are the following: its subjective-objective dichotomy, procedurality, objective "inhomogeneity" of facts, their system relation. They have made difficult to carry out integral civilization researches of the past because from the point of external observation it was impossible to establish both the unity of materials of historical sources and own immanent unity of historical facts usually taken as "atoms of history", only though imposing one or another philosophical theories. "Debunking" such meta-narratives, made by deconstructivism and poststucturalism, undermined trust to macro-history and put in doubt the history as a science.

Luhmann's systems sociological theory, created on interdisciplinary basis, allows for solving these issues in accordance with new achievements of post-non-classical science. It requires a new vision of the historical fact (fact-event, fact-source, and fact-knowledge) as manifestation of social communications. According to it, society is operationally closed communicative system and it functions as a change of meaningful communications (fact) by other at preserving meaningful 
relation between them and their modification. Using Luhmann's theory in historiography allows for revealing immanent meanings of certain historical events and, what is the most important, carrying out meaningful analysis of the whole civilization systems based on facts themselves but not on universalism theories. Civilization analysis is possible within the historical science directly, in particular, meaningful research of historical sources. Studying the history of civilization, it is recommended to take into account its hierarchical communicative, and therefore - textual structure and consistently analyze religious, powerful, local, and other communications in their interrelations in it.

\section{SUMMARY}

The article deals with the issue of scientific studying of historical fact. The author mentions that the traditional methodology of history was not able to reveal immanent coherence of facts to describe history as a coherent process. The main reason for that is in the fact that despite of all innovations there has been a traditional view of a historical fact as a "thing" regardless of its internal contradictions. It is almost impossible to solve the issue of subjective-objective dichotomy of the historical fact, historical source and historical studying as well.

Taking into account the above mentioned, it is recommended to apply post-non-classical systems theory by German sociologist Niklas Luhmann in the historical science that is built on the essential recognition of immanent systematic nature and immanent procedurality of the event in social systems. Its fundamental statement that the society does not consist of people but of communications, allows for overcoming the problem of subjective-objective dichotomy. The phenomena of communications (and it is every fact and historical source) removes from the agenda the issue about the objective and the subjective, since communication is both at the same time. Communications are possible not independently but only as elements of one or the other meaningful system. This makes the holistic studying of each civilization possible by means of the historical science itself.

\section{REFERENCES}

1. Мелков Ю.А. Факт в постнеклассической науке. К.: Издатель ПАРАПАН, 2004. 
2. Дюркгейм Э. Метод социологии // Дюркгейм Э. Социология. Ее предмет, метод, предназначение / Пер. с фр. М.: Канон, 1995. C. $18-40$.

3. Ковальченко И.Д. Методы исторического исследования. 2-е изд., доп. М.: Наука, 2003 [1987]. С. 143.

4.Ионов И.Н. Логические модели и источниковое знание: проблемы соотношения // История и синергетика: Методология исследования. М.: КомКнига, 2005. С. 45.

5.Гуревич А.Я. Что такое исторический факт? // Источниковедение. Теоретические и методологические проблемы. М.: Наука, 1969. С. 88.

6. Luhman N. Die Gesellschaft der Gesellschaft. Frankfurt am Main: Suhrkamp Verlag, 1977. $1150 \mathrm{~s}$.

7. Луман Н. Общество как социальная система. Пер с нем. М.: Изд-во «Логос», 2004. С. 63, 72-73, 92.

8. Луман Н. Медиа коммуникации. Пер с нем. М.: Изд-во «Логос», 2005. С. 19, 259-260.

9. Луман Н. Эволюция. Пер с нем. М.: Изд-во «Логос», 2005. С. 106.

10. Луман Н. Дифференциация. Пер с нем. М.: Изд-во «Логос», 2006.

11. Луман Н. Самоописания. Пер с нем. М.: Изд-во «Логос», 2009.

12. Антоновский А. Никлас Луман: эпистемологические основания и источники социологического конструктивизма // Луман Н. Общество как социальная система. Пер с нем. М.: Изд-во «Логос», 2004. C. 208-209.

13. Лоренц К. Обратная сторона зеркала. М.: Республика, 1998. C. 457.

\section{Information about the author: Kosmyna V. G. \\ Doctor of Historical Sciences,} Assistant Professor at the Department of Philosophy and History Educational and Scientific Humanitarian Institute of V. I. Vernadsky Taurida National University, 33, Ivana Kudri str., Kyiv, Ukraine 